\title{
Study on Preparation and Quality Standard of compound Antibacterial Gel of DianDaoSan
}

\author{
Gao Ting, Long Guangchi, Xu Yunhua, Zeng Zuting, Yang Min*
}

Jilin Agricultural Science and Technology University, Jilin, Jilin, 132101

Keywords: Compound upside down powder, Carbomer, glycerol, triethanolamine, Gelatin, quality standard

\begin{abstract}
The objective of this paper is to prepare the compound antibacterial gel of DianDaoSan and establish the quality standard of the compound antibacterial gel of DianDaoSan. The investigation of gel matrix compound Diandao pulvis antibacterial gel dosage, namely, the effect of Carbomer, triethanolamine, glycerol contenton antibacterial compound DianDao pulvis gel appearance uniformity, viscosity, stability of cold thermalstability and centrifugal stability, screen out the best process. The results show that Carbomer, glycerol and when the dosage of triethanolamine is $0.8 \mathrm{~g}, 3 \mathrm{~g}, 0.7 \mathrm{~g}$, the gel has a good homgenization and viscosity, the cold resistant, heat resistant and centrifuge are more stable. In this subject, the preparation technology and quality standard of this preparation are studied to provide reference for the future research and development of the new drug delivery system for the treatment of acne.
\end{abstract}

This subject adopts Professor Yang Liu according to TCM compound DianDao pulvis based on adding in aloe, phellodendron and other traditional Chinese medicine developed from the San $^{[1]}$, its years of clinical observation has confirmed the antimicrobial efficacy of Qucuo, and the original formulation of improvement for the gel, in order to prepare a new Chinese traditional medicine formulation, effective and convenient for patients to use, expand the scope of use, reversely scattered in the clinic to improve the safety of clinical medication, and provide a new direction for the development of Chinese compound external preparation.

\section{Instruments and reagents}

FA1004 electronic balance (Shanghai flat Instrument Co. Ltd.); CLF-30 B mill (Zhejiang province Wenling Chuangli medicine instrument factory); DHG-9055 type electrothermostat (Shanghai Bozhen instrument equipment factory); HH-2 digital constant temperature water bath box (Jintan Tianrui Instrument Co., Ltd.); BCD-186U refrigerator (Shanghai Pearl electrical appliance Co. company TDZ4WS (Hunan); balance centrifuge Xiangyi Laboratory Instrument Development Co. Ltd. (Jilin); rhubarb, phellodendron, Jilin Ren Tang Chinese Medicine Museum); aloe (Jilin Jilin pharmacy); sulfur (mountain sub chemical Limited by Share Ltd); Carbomer, triethanolamine (Chengdu Huayi medicinal materials manufacturing Co., Ltd.) glycerol; (Hunan Kang pharmaceutical Limited by Share Ltd).

\section{Methods and results}

According to the extraction method of Professor Yang ${ }^{[2]}$, the botanical rhubarb, Phellodendron Amur and aloe were first added 10 times the amount of water according to the prescribed dosage, decocted $2 \mathrm{~h}$, second times plus 8 times of water, decocted $1 \mathrm{H}$, filtered two times of filter residue, combined with filtrate, heated and concentrated into extract, weighing $5 \mathrm{~g}$.

Refer to the relevant literature to determine the basic formula for $0.6 \mathrm{~g}{ }^{[3]}$ gel carbomer $5 \mathrm{~g}$, glycerol $0.5 \mathrm{~g}$, triethanolamine, amount of distilled water, drug extract $5 \mathrm{~g}, 1$ sulfur $5 \mathrm{~g}$, ethyl 0. 05g. Weighing $0.6 \mathrm{~g}$ carbomer into the beaker, then take $25 \mathrm{~mL}$ of distilled water into the beaker containing Carbomer, its standing overnight, to be fully swelling carbomer. $5 \mathrm{~g} 5 \mathrm{~g}$ and sublimed sulfur and glycerol mixed, weighed sieve No. 8 fully mixing, the mixing, add it to the carbomer 
swelling, while adding the edge, uniform mixing, mixing it, adding triethanolamine $0.5 \mathrm{~g}$, in the same direction and uniform stirring to complete mixing, measuring the amount of $\mathrm{pH}$ value neutral. The medicine mixing 0.05g extract and Ethylparaben, then added to the blank gel, uniformly stirring until the complete mixing, plus the amount of distilled water to $50 \mathrm{~g}$ gel, gel agent, packing to box, each box of $10 \mathrm{G}$ seal. Preliminary experiments found that the gel is relatively rare, also found that carbomer and triethanolamine have thickening effect, the best formula needs to be investigated by single factor test and orthogonal test analysis.

The optimum formula of the gel was determined by the comprehensive scoring method ${ }^{[4]}$ the more the score, the closer the gel was to the requirement of the ideal gel. The comprehensive scoring method uses multiple standards, according to the score of each standard, and then calculates the total score, and uses the total score to analyze the finished product. The total score of each standard was 100 points, of which gel appearance uniformity accounted for 20 points, gel viscosity accounted for 30 , heat stability accounted for 15, cold stability accounted for 15, centrifugal stability accounted for 20 points. The specific criteria are as follows:

Table 1 Scoring criteria

\begin{tabular}{|c|c|c|c|}
\hline $\begin{array}{l}\text { the inspection } \\
\text { standard of the gel }\end{array}$ & \multicolumn{3}{|c|}{ evaluation methodology } \\
\hline $\begin{array}{l}\text { the homogeneity of } \\
\text { gel } \\
\text { (20points) }\end{array}$ & $\begin{array}{l}\text { (18 20points) } \\
\text { good: the gel is fine } \\
\text { and has not } \\
\text { precipitate }\end{array}$ & $\begin{array}{l}\text { (15 18points) } \\
\text { ordinary:the gel is } \\
\text { not uniform and } \\
\text { has not precipitate }\end{array}$ & $\begin{array}{l}\text { (15points below) } \\
\text { poor: the gel is not } \\
\text { uniform and has } \\
\text { precipitate }\end{array}$ \\
\hline $\begin{array}{l}\text { the viscosity of gel } \\
\text { (30points) }\end{array}$ & $\begin{array}{l}(25 \sim 30 \text { points }) \\
\text { ropiness }\end{array}$ & $\begin{array}{l}\text { (15 25points) } \\
\text { thin }\end{array}$ & $\begin{array}{l}\text { (15points below0 } \\
\text { very thin }\end{array}$ \\
\hline $\begin{array}{l}\text { the cold-resistance } \\
\text { stability } \\
\text { (15points) }\end{array}$ & $\begin{array}{l}\text { (13 15points) } \\
\text { good: the gel is not } \\
\text { stratified, and there } \\
\text { is no variations in } \\
\text { appearance }\end{array}$ & $\begin{array}{l}\text { (10 13points) } \\
\text { oridinary: the gel is } \\
\text { not } \\
\text { stratified,with } \\
\text { slight variations in } \\
\text { appearance }\end{array}$ & $\begin{array}{l}\text { (10points below) } \\
\text { poor: the gel is } \\
\text { layered and has a } \\
\text { noticeable change } \\
\text { in appearance }\end{array}$ \\
\hline $\begin{array}{l}\text { the heat-resistance } \\
\text { stability } \\
\text { (15points) }\end{array}$ & $\begin{array}{l}\text { (13 15points) } \\
\text { good: the gel is not } \\
\text { stratified,and there } \\
\text { is no variations in } \\
\text { appearance }\end{array}$ & $\begin{array}{l}\text { (10 13points) } \\
\text { oridinary: the gel is } \\
\text { not } \\
\text { stratified,with } \\
\text { slight variations in } \\
\text { appearance }\end{array}$ & $\begin{array}{l}\text { (10points below) } \\
\text { poor: the gel is } \\
\text { layered and has a } \\
\text { noticeable change } \\
\text { in appearance }\end{array}$ \\
\hline $\begin{array}{l}\text { centrifugal stability } \\
\text { (20points) }\end{array}$ & $\begin{array}{l}\text { (17 20points) } \\
\text { good:the gel is not } \\
\text { stratified,and there } \\
\text { is no variations in } \\
\text { appearance }\end{array}$ & $\begin{array}{l}\text { (13 17points) } \\
\text { oridinary:the gel } \\
\text { has a slight } \\
\text { stratification and } \\
\text { no change in } \\
\text { appearance }\end{array}$ & $\begin{array}{l}\text { (13points below) } \\
\text { poor: the gel is } \\
\text { layered and has a } \\
\text { noticeable change } \\
\text { in appearance }\end{array}$ \\
\hline
\end{tabular}


Table 2 Carbomer gel effects on the traits of Cabo homogeneity

\begin{tabular}{|c|c|c|c|c|c|c|}
\hline $\begin{array}{l}\text { carb-omer } \\
\text { amou-nt(g) }\end{array}$ & uniformity & viscosity & $\begin{array}{l}\text { the } \\
\text { cold-resist-ance } \\
\text { stability }\end{array}$ & $\begin{array}{l}\text { the } \\
\text { heat-resista-nce } \\
\text { stability }\end{array}$ & $\begin{array}{l}\text { centrifugal } \\
\text { stability }\end{array}$ & Sc-ore \\
\hline 0.4 & $\begin{array}{l}\text { oridinary } \\
\text { (16points) }\end{array}$ & $\begin{array}{l}\text { very thin } \\
\text { (12points) }\end{array}$ & $\begin{array}{c}\text { poor } \\
\text { (8points) }\end{array}$ & $\begin{array}{c}\text { oridinary } \\
\text { (10points) }\end{array}$ & $\begin{array}{l}\text { Oridinary } \\
\text { (9points) }\end{array}$ & 55 \\
\hline 0.5 & $\begin{array}{l}\text { oridinary } \\
\text { (17points) }\end{array}$ & $\begin{array}{l}\text { very thin } \\
\text { (13points) }\end{array}$ & $\begin{array}{c}\text { poor } \\
\text { (10points) }\end{array}$ & $\begin{array}{l}\text { oridinary } \\
\text { (11points) }\end{array}$ & $\begin{array}{c}\text { Good } \\
\text { (13points) }\end{array}$ & 64 \\
\hline 0.6 & $\begin{array}{l}\text { oridinary } \\
\text { (17points) }\end{array}$ & $\begin{array}{l}\text { thin } \\
\text { (22points) }\end{array}$ & $\begin{array}{l}\text { oridinary } \\
\text { (15points) }\end{array}$ & $\begin{array}{l}\text { good } \\
\text { (13points) }\end{array}$ & $\begin{array}{c}\text { Good } \\
\text { (14points) }\end{array}$ & 81 \\
\hline 0.7 & $\begin{array}{c}\text { good } \\
\text { (18points) }\end{array}$ & $\begin{array}{l}\text { ropiness } \\
\text { (27points) }\end{array}$ & $\begin{array}{c}\text { good } \\
\text { (18points) }\end{array}$ & $\begin{array}{c}\text { good } \\
\text { (13points) }\end{array}$ & $\begin{array}{l}\text { good } \\
\text { (14points) }\end{array}$ & 90 \\
\hline 0.8 & $\begin{array}{c}\text { good } \\
\text { (17points) }\end{array}$ & $\begin{array}{l}\text { ropiness } \\
\text { (27points) }\end{array}$ & $\begin{array}{c}\text { good } \\
\text { (17points) }\end{array}$ & $\begin{array}{c}\text { good } \\
\text { (13points) }\end{array}$ & $\begin{array}{c}\text { good } \\
\text { (14points) }\end{array}$ & 88 \\
\hline
\end{tabular}

From the table we can see that card, homogeneity of the gel viscosity Bohm, obvious effect, the amount is too small, the uniformity of gel viscosity, bad; dosage increased, gel stability change. The amount of carbopol $0.7 \mathrm{~g}$ and $0.8 \mathrm{~g}$ gel uniformity and good viscosity, good stability.

Table 3 The effect of glycerin on the gel properties

\begin{tabular}{|c|c|c|c|c|c|c|}
\hline $\begin{array}{l}\text { glyce-rol } \\
\text { amou-nt(g) }\end{array}$ & Homogenei-ty & viscosity & $\begin{array}{l}\text { Centrifuga-l } \\
\text { stability }\end{array}$ & $\begin{array}{c}\text { heat-resist-ant } \\
\text { stability }\end{array}$ & $\begin{array}{l}\text { cold-resist-ant } \\
\text { stability }\end{array}$ & Sc-ore \\
\hline 3 & $\begin{array}{l}\text { good } \\
\text { (17points) }\end{array}$ & $\begin{array}{l}\text { ropiness } \\
\text { (28points) }\end{array}$ & $\begin{array}{c}\text { good } \\
\text { (19points) }\end{array}$ & $\begin{array}{c}\text { good } \\
\text { (14points) }\end{array}$ & $\begin{array}{c}\text { good } \\
\text { (13points) }\end{array}$ & 91 \\
\hline 4 & $\begin{array}{c}\text { good } \\
\text { (17points) }\end{array}$ & $\begin{array}{l}\text { ropiness } \\
\text { (27points) }\end{array}$ & $\begin{array}{c}\text { good } \\
\text { (19points) }\end{array}$ & $\begin{array}{c}\text { good } \\
\text { (13points) }\end{array}$ & $\begin{array}{l}\text { general } \\
\text { (11points) }\end{array}$ & 87 \\
\hline 5 & $\begin{array}{c}\text { good } \\
\text { (18points) }\end{array}$ & $\begin{array}{l}\text { ropiness } \\
\text { (27points) }\end{array}$ & $\begin{array}{l}\text { general } \\
\text { (15points) }\end{array}$ & $\begin{array}{l}\text { general } \\
\text { (12points) }\end{array}$ & $\begin{array}{l}\text { general } \\
\text { (11points) }\end{array}$ & 83 \\
\hline 6 & $\begin{array}{l}\text { general } \\
\text { (16points) }\end{array}$ & $\begin{array}{c}\text { thin } \\
\text { (20points) }\end{array}$ & $\begin{array}{l}\text { general } \\
\text { (14points) }\end{array}$ & $\begin{array}{l}\text { general } \\
\text { (11points) }\end{array}$ & $\begin{array}{l}\text { General } \\
\text { (10points) }\end{array}$ & 71 \\
\hline 7 & $\begin{array}{l}\text { general } \\
\text { (15points) }\end{array}$ & $\begin{array}{c}\text { thin } \\
\text { (18points) }\end{array}$ & $\begin{array}{c}\text { poor } \\
\text { (12points) }\end{array}$ & $\begin{array}{c}\text { poor } \\
\text { (9points) }\end{array}$ & $\begin{array}{l}\text { general } \\
\text { (10points) }\end{array}$ & 64 \\
\hline
\end{tabular}

It can be seen from the table that glycerol has obvious influence on the homogeneity, viscosity and stability of the gel. When the amount is too much, glycerol has a homogeneity, viscosity is not good, and its stability is not good. When the dosage is reduced, the appearance and stability of the gel change. When the dosage is $3 g$, the gel is homogeneity, the viscosity is better, and the stability is good.

Table 4 Effect of triethanolamine on gel properties

\begin{tabular}{|c|c|c|c|c|c|c|}
\hline $\begin{array}{c}\text { triethanolamine } \\
\text { amoun-t(g) }\end{array}$ & homogeneit-y & viscosity & $\begin{array}{c}\text { centrifugal } \\
\text { stability }\end{array}$ & $\begin{array}{c}\text { heat-resist-ant } \\
\text { stability }\end{array}$ & $\begin{array}{l}\text { cold-resist- } \\
\text { ant stability }\end{array}$ & Sc-ore \\
\hline 0.3 & $\begin{array}{l}\text { general } \\
\text { (16points) }\end{array}$ & $\begin{array}{l}\text { very thin } \\
\text { (11points) }\end{array}$ & $\begin{array}{l}\text { g eneral } \\
\text { (13points) }\end{array}$ & $\begin{array}{c}\text { poor } \\
\text { (9points) }\end{array}$ & $\begin{array}{c}\text { general } \\
\text { (10points) }\end{array}$ & 59 \\
\hline 0.4 & $\begin{array}{l}\text { General } \\
\text { (16points) }\end{array}$ & $\begin{array}{c}\text { thin } \\
\text { (16points) }\end{array}$ & $\begin{array}{l}\text { general } \\
\text { (14points) }\end{array}$ & $\begin{array}{l}\text { general } \\
\text { (11points) }\end{array}$ & $\begin{array}{l}\text { general } \\
\text { (10points) }\end{array}$ & 67 \\
\hline 0.5 & $\begin{array}{l}\text { general } \\
\text { (17points) }\end{array}$ & $\begin{array}{c}\text { thin } \\
\text { (17points) }\end{array}$ & $\begin{array}{l}\text { general } \\
\text { (16points) }\end{array}$ & $\begin{array}{l}\text { general } \\
\text { (12points) }\end{array}$ & $\begin{array}{l}\text { general } \\
\text { (12points) }\end{array}$ & 74 \\
\hline 0.6 & $\begin{array}{l}\text { general } \\
\text { (16points) }\end{array}$ & $\begin{array}{l}\text { ropiness } \\
\text { (25points) }\end{array}$ & $\begin{array}{l}\text { good } \\
\text { (17points) }\end{array}$ & $\begin{array}{c}\text { good } \\
\text { (13points) }\end{array}$ & $\begin{array}{l}\text { good } \\
\text { (14points) }\end{array}$ & 85 \\
\hline 0.7 & $\begin{array}{c}\text { gGood } \\
\text { (18points) }\end{array}$ & $\begin{array}{l}\text { ropiness } \\
\text { (26points) }\end{array}$ & $\begin{array}{c}\text { good } \\
\text { (18points) }\end{array}$ & $\begin{array}{c}\text { good } \\
\text { (14points) }\end{array}$ & $\begin{array}{c}\text { good } \\
\text { (14points) }\end{array}$ & 90 \\
\hline
\end{tabular}

It can be seen from the table that triethanolamine has great influence on the viscosity of the gel. When the amount of triethanolamine is too small, the viscosity of the gel is relatively thin, and its heat resistance and cold stability are not good. When the dosage of triethanolamine is $0.6 \mathrm{~g}$ and $0.7 \mathrm{~g}$, the viscosity is better, the centrifugal stability, the stability of heat resistance and the stability of 
cold resistance are better.

The gel is uniform and delicate and keeps colloid at normal temperature. It does not dry up or liquefy.

The gel agent $10 \mathrm{~g}$ was put into the distilled water of $120 \mathrm{ml}$, and the $\mathrm{pH}$ value was 7.2 after the gel was completely dissolved, which was in line with the requirements of the Chinese Pharmacopoeia.

The prepared gel into $10 \mathrm{~mL}$ centrifuge tube for refrigerator, will it into $-5 \mathrm{C}$ and $10 \mathrm{C}$ in $24 \mathrm{~h}, 24 \mathrm{~h}$ out after return to room temperature, gel properties had no obvious change; the prepared gel loaded $10 \mathrm{~mL}$ centrifuge tube will be put into the system, $(40+1) \mathrm{C}$ in thermotank $24 \mathrm{~h}$, after $24 \mathrm{~h}$ return to room temperature, gel properties had no obvious change.

The prepared gel was divided into 5 parts and loaded into the $10 \mathrm{ml}$ centrifuge tube respectively. The centrifuge was placed in the centrifuge at the speed of 4000r. The gel was taken out after $40 \mathrm{Mn}$, and there was no obvious change in the gel character.

Randomly selected three samples, according to the China Pharmacopoeia 2015 edition, bacteriostatic effect check law (1121), microbial count law (1105), the control bacteria test law (1106) and non sterile drug for microbial limits (1107) determination of Charkin fungus, Staphylococcus aureus, Escherichia coli, Pseudomonas aeruginosa meet the standards.

Table 5 Orthogonal design factor level table for the dosage of gel matrix

\begin{tabular}{cccc}
\hline level & \multicolumn{3}{c}{ factor } \\
& A & B & C \\
\hline 1 & 0.6 & 3 & 0.5 \\
2 & 0.7 & 4 & 0.6 \\
3 & 0.8 & 5 & 0.7 \\
\hline
\end{tabular}

Note: A, B, C in turn said: carbomer, glycerine, triethanolamine.

Table 6 Orthogonal test table for the dosage of gelling excipient

\begin{tabular}{cccc}
\hline Test number & A & B & C \\
\hline 1 & 1 & 1 & 1 \\
2 & 1 & 2 & 2 \\
3 & 1 & 3 & 3 \\
4 & 2 & 1 & 2 \\
5 & 2 & 2 & 3 \\
6 & 2 & 3 & 1 \\
7 & 3 & 1 & 3 \\
8 & 3 & 2 & 1 \\
9 & 3 & 3 & 2 \\
\hline
\end{tabular}

Table 7 Orthogonal test results of the dosage of gelling excipient

\begin{tabular}{ccccccc}
\hline number & homogen-eity & viscosity & $\begin{array}{c}\text { centrifugal } \\
\text { stability }\end{array}$ & $\begin{array}{c}\text { heat-resist-ant } \\
\text { stability }\end{array}$ & $\begin{array}{c}\text { cold-resista-nt } \\
\text { stability }\end{array}$ & score \\
\hline 1 & good & very thin & good & general & general & 80 \\
2 & general & very thinl & general & poor & general & 74 \\
3 & good & very thinl & general & good & general & 81 \\
4 & good & ropiness & general & general & general & 82 \\
5 & good & ropiness & general & general & general & 83 \\
6 & good & very thinl & general & general & poor & 78 \\
7 & general & ropiness & good & good & good & 89 \\
8 & good & ropiness & general & general & general & 80.5 \\
9 & general & ropiness & general & general & general & 79 \\
\hline
\end{tabular}


Table 8 Analysis of the results of orthogonal test for the dosage of gelling excipients

\begin{tabular}{cccc}
\hline test number & $\mathrm{A}$ & $\mathrm{B}$ & $\mathrm{C}$ \\
\hline $\mathrm{K}_{1}$ & 235 & 251 & 238.5 \\
$\mathrm{~K}_{2}$ & 243 & 237.5 & 235 \\
$\mathrm{~K}_{3}$ & 248.5 & 238 & 253 \\
$\mathrm{k}_{1}$ & 78.33 & 83.67 & 79.5 \\
$\mathrm{k}_{2}$ & 81 & 79.16 & 78.33 \\
$\mathrm{k}_{3}$ & 82.83 & 79.33 & 84.33 \\
$\mathrm{R}$ & 4.50 & 4.51 & 6.00 \\
\hline
\end{tabular}

Note: $\mathrm{K}$ indicates the sum of the comprehensive scores of each factor, and $\mathrm{K}$ indicates the average value of the comprehensive score of each factor, and the $\mathrm{R}$ is the extreme.

According to the size of the extreme difference in table 9, the influence degree of each factor on the comprehensive score is $\mathrm{C}>\mathrm{B}>\mathrm{A}$, and it can be obtained from the comprehensive average of all levels of the factors: A takes A3, B takes B1, C takes C3, the comprehensive score is the best. Therefore, the best preparation process of granules for A3B1C3, namely: carbomer: triethanolamine glycerol at the ratio of 8:30:7.

Table 9 Orthogonal test variance analysis

\begin{tabular}{ccccccc}
\hline $\begin{array}{c}\text { variance } \\
\text { source }\end{array}$ & $\begin{array}{c}\text { sum of } \\
\text { sguares of } \\
\text { deviation from } \\
\text { mean }\end{array}$ & $\begin{array}{c}\text { Degree of } \\
\text { freedo-m }\end{array}$ & $\begin{array}{c}\text { Mean } \\
\text { squar-e }\end{array}$ & $\begin{array}{c}\mathrm{F} \\
\text { value }\end{array}$ & Fcritical value & Signif-icant \\
\hline A & 30.722 & 2 & 15.36 & 29.10 & $\mathrm{~F}_{0.05}(2,2)=19, \mathrm{~F}_{0.01}(2,2)=99$ & $*$ \\
B & 39.056 & 2 & 19.52 & 37.00 & $\mathrm{~F}_{0.05}(2,2)=19, \mathrm{~F}_{0.01}(2,2)=99$ & $*$ \\
C & 60.722 & 2 & 30.36 & 57.52 & $\mathrm{~F}_{0.05}(2,2)=19, \mathrm{~F}_{0.01}(2,2)=99$ & $*$ \\
error & 1.056 & & & & & \\
\hline
\end{tabular}

From table 9, FA $>$ F0.05 $(2,2)=19$, then $\mathrm{P}<0.05$, is rejected at 0.05 significant levels Ho, which has a significant influence that accept $\mathrm{H} 1$ score of a factors and the amount of carbopol gel; $\mathrm{FB}>\mathrm{F} 0.05(2,2)=19$, then $\mathrm{P}<0.05$, so Ho is refused at the 0.05 significant level, and $\mathrm{H} 1$ is accepted, indicating the $\mathrm{B}$ factor,the dosage of glycerol has a significant influence on the comprehensive score of the gel; Fc $>$ F0.05 $(2,2)=19$, then $\mathrm{P}<0.05$, at the 0.05 significant level, Ho was rejected and $\mathrm{H} 1$ was accepted. It also indicated that the dosage of $\mathrm{C}$ factor triethanolamine had a significant effect on the comprehensive score of the gel.

According to the orthogonal test results, the optimum preparation process condition A3B1C3 was selected to verify the test. Namely, Carbomer 0.8g, glycerol 3g, triethanolamine $7 \mathrm{~g}$. As a result, see table 10 .

Table 10 Verification test results

\begin{tabular}{|c|c|c|c|c|c|c|}
\hline $\begin{array}{c}\text { Test } \\
\text { number }\end{array}$ & homogeneity & viscosity & $\begin{array}{l}\text { centrifugal } \\
\text { stability }\end{array}$ & $\begin{array}{l}\text { heat-resistant } \\
\text { stability }\end{array}$ & $\begin{array}{l}\text { Cold-resist-ant } \\
\text { stability }\end{array}$ & score \\
\hline 1 & $\begin{array}{c}\text { general } \\
\text { (17points) }\end{array}$ & $\begin{array}{l}\text { Ropiness } \\
\text { (29points) }\end{array}$ & $\begin{array}{c}\text { good } \\
\text { (18points) }\end{array}$ & good (14points) & $\begin{array}{c}\text { good } \\
\text { (13points) }\end{array}$ & 91 \\
\hline 2 & $\begin{array}{l}\text { general } \\
\text { (17points) }\end{array}$ & $\begin{array}{l}\text { ropiness } \\
\text { (28points) }\end{array}$ & $\begin{array}{c}\text { good } \\
\text { (18points) }\end{array}$ & good (13points) & $\begin{array}{c}\text { good } \\
\text { (14points) }\end{array}$ & 90 \\
\hline 3 & $\operatorname{good}(18 p o i n t s)$ & $\begin{array}{l}\text { ropiness } \\
\text { (28points) }\end{array}$ & $\begin{array}{c}\text { good } \\
\text { (18points) }\end{array}$ & good (14points) & $\begin{array}{c}\text { good } \\
\text { (14points) }\end{array}$ & 92 \\
\hline
\end{tabular}

It is shown in table 10 that the test results are close to the experimental results, and the process is basically stable and reliable. 


\section{Conclusion and discussion}

In this study, the plant extract was extracted and condensed into a drug extract, and then added to the blank gel to make a gel. The better level effect of single factor test to optimize excipients on the gel gel characteristics, analysis the conclusion by intuition: compound Diandao pulvis gel modified the best preparation process was A3B1C3, carbomer was 0.8g, glycerol $3 \mathrm{~g}$, triethanolamine concentration is $0.7 \mathrm{~g}$, the prepared gel uniformity, good viscosity, cold resistance property, heat resistance and centrifugal stability. By the comprehensive score variance analysis shows that A factors that card comprehensive score of the gel was significantly affected, significantly affected the score of B factors on glycerol gel, significantly affected the score of C factors of triethanolamine on gel. The gel preparation technology is easy to operate, safe and effective, and has great application prospects. It has a certain reference value for the research and development of Ru products.

\section{Acknowledgement}

Fund Projects: Jilin College of Agricultural Science and Technology Student Innovation Funding Project, Contract No.: Jilin College of Agriculture Synopsis[2017] No. 006.

\section{References}

[1-2] Wu Jing, Chen Ying, Huang Qitao, Li Shumin, Zhen new, Zheng Shuili, Guo Tingting, Chen Sisheng. Compound Diandao pulvis drug facial mask preparation and clinical efficacy [J]. Shizhen medical medicine, 2009,20 (07): 1786-1787.

[3] Li Mingyan, red party. Compound Chinese medicine scald gel preparation and quality control[J]. China hospital pharmacy Journal 20103030 (03): 247-248.

[4] Ma Li. Tea seed oil in the application of emollient cream [D]. Hunan Agricultural University, 2008.

[5] Fu Jilin.The preparation and research of compound Chinese medicine gel[D]. Jilin University, 2016.

[6] Liu Haohua, Zhang Xiaojun, Chen Limei. Compound aloe gel preparation and clinical application[J]. Journal of practical medical technical 2008 (18): 2377-2379.

[7] Wang Yan, Wang Zijuan. Preparation and quality control of compound Salicylic Acid Gel [J]. China Journal of hospital medicine.2005 (04): 340-34.

[8] Pan Jie, Zhang Hong. Preparation and quality control of compound ginseng gel[J]. Guide of Chinese medicine, 2015,21 (10): 5356.

Communication writer: Yangmin (1984-), female, Han nationality, Jilin province, Jilin province, master, research direction is the foundation of traditional Chinese medicine, Chinese pharmacy. Email: yangmin 7426@126.com.

Introduction of the first author: Gaoting (1997-), female, Han nationality, wujiaqu city, Xinjiang, undergraduate, research direction is Chinese pharmacy. Email: 1391720952@qq.com 